\title{
TAFSIR ‘ILMI
}

\section{Rubini}

Keahlian Ilmu Pendidikan Islam

Dosen Program Studi Pendidikan Agama Islam STAIMS Yogyakarta

Alamat e-mail : rubyhz@yahoo.com

\begin{abstract}
ABSTRAK
Tafsir 'ilmi adalah tafsir yang menggunakan istilah-istilah ilmiah dalam mendiskripsikan al-Qur'an dan berusaha keras untuk mengeluarkan berbagai ilmu pengetahuan dan visi filsafat darinya. Dalam menanggapi tafsir 'ilmi ini, para ulama ada dua kelompok yakni menolak dan mendukung. Bahkan banyak ulamaulama kontemporer yang bersikap lebih moderat seperti alGhamrawi. Kita tidak bisa mengklaim kebenaran bahwa teori-teori ilmiah ini adalah sebagai bentuk final dari penafsiran ayat, dalam artian al-Qur'an adalah bukan kitab ilmu pengetahuan melainkan kitab yang menjadi petunjuk dan rahmat bagi kehidupan manusia baik spiritual maupun material yang bisa dikembangkan melalui ilmu pengetahuan.
\end{abstract}

\section{Kata kunci : 'ilmi, filsafat. ulama'}

\section{ABSTRACT}

Tafsir 'ilmi is the interpretation which uses scientific terms in describing the Qur'an and strive to bring a variety of knowledge and vision of philosophy from him. In response to interpretation 'ilmi this , the scholars there are two groups reject and support. Even many contemporary scholars who were more moderate as al - Ghamrawi. We can not claim to truth that scientific theories are as the final form of the exegesis of the text, in the sense that the Qur'an is not a book of science, but the book is a guidance and a mercy for human life both spiritual and material that can be developed through the science knowledge.

\section{Keywords : science, philosophy, ulama.}

\section{A. Pendahuluan}

Al-Qur'an adalah kitab suci umat islam, di dalam kitab tersebut ternyata tidak hanya mengandung ayat-ayat yang 
berdimensi aqidah, syari'ah dan akhlaq semata, akan tetapi juga memberikan perhatian yang sangat besar bagi perkembangan ilmu pengetahuan (sains). Jika kita membaca Al-Qur'an secara seksama, akan kita temukan begitu banyak ayat-ayat yang mengajak kepada manusia untuk bersikap ilmiah, berdiri di atas prinsip pembebasan akal dari takhayul dan kebebasan akal untuk berpikir. Al-Qur'an selalu mengajak manusia untuk melihat, membaca, memperhatikan, memikirkan, mengkaji serta memahami dari setiap fenomena yang ada terlebih lagi terhadap fenomena-fenomena alam semesta yang perlu mendapatkan perhatian khusus karena darinya bisa dikembangkan sains dan teknologi untuk perkembangan umat manusia dan dengan itu pula akan didapatkan pemahaman yang utuh dan lengkap.

Bukan hanya itu, ayat yang pertama kali diturunkan kepada Rasulullah SAW merupakan perintah untuk membaca (ا قرا) yang menurut Quraish Shihab, kata ini terambil dari akar kata qara'a (قرا ) yang berarti menghimpun. Dari menghimpun lahir aneka makna seperti menyampaikan, menelaah, mendalami, meneliti, mengetahui ciri sesuatu, dan membaca baik teks yang tertulis maupun tidak. ${ }^{1}$ Karena kata ini objeknya bersifat umum sehingga maknanya mencakup segala sesuatu yang bisa dijangkaunya, baik yang tersurat maupun yang tersirat, ayat-ayat qauliyyah maupun kauniyyah. Jika demikian adanya merupakan hal yang wajar jika orang-orang yang berpengetahuan mendapatkan derajat yang lebih tinggi karena tidaklah sama antara orang-orang

${ }^{1}$ M.Quraish Shihab, Wawasan Al-Qur'an: Tafsir Maudhu'i Atas Pelbagai Persoalan Umat, Cet.VIII. (Bandung: Mizan, 1998) hlm. 433 
yang berilmu pengetahuan dengan yang tidak berpengetahuan.

Adapun terhadap ayat-ayat kauniyyah dari ayat-ayat alQur'an, memang tidak ada yang secara tegas dan khusus ditujukan kepada para ilmuwan untuk mengkaji, namun pada hakikatnya, mereka inilah yang diharapkan untuk terjun melakukan penelitian dan mengkaji serta memahami maknamakna yang tersurat dan yang tersirat dari ayat-ayat kawniyyah. Karena hanya orang-orang yang ahli dan mempunyai saran serta kompetensi dalam bidangnyalah yang bisa dan mampu untuk menggali secara lebih komprehensif dan teliti dalam melakukan tugas tersebut sehingga hasil dari kajian dan penelitian tersebut akan benar-benar memberikan manfaat bagi umat manusia.

Dengan demikian, besar harapan para ilmuwan-ilmuwan muslim tergerak dan termotivasi untuk mengeksplorasi ayatayat al-Qur'an yang berdimensi ilmiah dan berusaha menafsirkan serta menggali makna yang terkandung di dalamnya serta menjadikannya sebagai inspirasi untuk menghasilkan penemuan-penemuan baru yang bermanfaat bagi umat manusia dan dengan semakin berkembangnya sains dan teknologi ini pula mendorong munculnya corak baru dalam bidang penafsiran yang dikenal pada saat ini sebagai penafsiran ilmiah atau Tafsir 'Ilmi (Sciences Exegesis) yang cukup banyak menarik perhatian para intelektual muslim dan permasalahan (Tafsir 'Ilmi) ini pula yang akan menjadi pokok pembahasan penulis dalam makalah ini.

\section{B. Pengertian Tafsir 'Ilmi}

Pada dasarnya al-Qur'an adalah kitab suci yang menetapkan masalah akidah dan hidayah, hukum syari'at 
dan akhlak. Bersamaan dengan hal itu, di dalamnya di dapati juga ayat-ayat yang menunjukkan tentang berbagai hakikat (kenyataan) ilmiah yang memberikan dorongan kepada manusia untuk mempelajari, membahas dan menggalinya. Sejak zaman dahulu sebagian kaum muslimin telah berusaha menciptakan hubungan seerat-eratnya antara al-Qur'an dan ilmu pengetahuan. Mereka berijtihad menggali beberapa jenis ilmu pengetahuan dari ayat-ayat al-Qur'an, dan di kemudian hari usaha ini semakin meluas, dan tidak ragu lagi, hal ini telah mendatangkan hasil yang banyak faedahnya. ${ }^{2}$

Adapun pengertian tafsir ilmi atau yang dalam terminologi Jansen disebut sebagai sejarah alam secara sederhana dapat didefinisikan sebagai usaha memahami ayatayat al-Qur'an dengan menjadikan penemuan-penemuan sains modern sebagai alat bantunya. Ayat al-Qur'an di sini lebih diorientasikan kepada teks yang secara khusus membicarakan tentang fenomena kealaman atau yang biasa dikenal sebagai al-ayat al-kauniyat. Jadi yang dimaksud dengan tafsir 'ilmi adalah suatu ijtihad atau usaha keras seorang mufassir dalam mengungkapkan hubungan ayat-ayat kauniyah dalam al-Qur'an dengan penemuan-penemuan sains modern, yang bertujuan untuk memperlihatkan kemukjizatan al-Qur'an. ${ }^{3}$

Tafsir ilmi adalah menafsirkan ayat-ayat al-Qur'an berdasarkan pendekatan ilmiah atau menggali kandungan alQur'an berdasarkan teori-teori ilmu pengetahuan. Ayat-ayat

2 Muhammad Nor Ichwan. Memasuki Dunia Al-Qur'an. (Semarang: Lubuk Raya, 2001) hlm 253

3 Muhammad Nor Ichwan. Tafsir 'Ilmiy Memahami Al-Qur'an Melalui Pendekatan Sains Modern. (Yogyakarta: Menara Kudus, 2004) hlm 127 
al-Qur'an yang di tafsirkan dalam corak tafsir ini adalah ayatayat kauniyah (kealaman). ${ }^{4}$

Tafsir 'ilmi atau scientific exegies dalah corak penafsiran al-Qur'an yang menggunakan pendekatan teori-teori ilmiah untuk menjelaskan ayat-ayat al-Qur'an. Tafsir ilmi di maksudkan untuk menggali teori-teori ilmiah dan pemikiran filosofis dari ayat-ayat al-Qur'an juga di maksudkan untuk justifikasi dan mengkompromikan teori-teori ilmu pengetahuan dengan al-Qur'an serta bertujuan untuk mendeduksikan teori-teori ilmu pengetahuan dari ayat-ayat al-Qur'an itu sendiri. ${ }^{5}$

Berdasarkan beberapa definisi di atas dapat kita pahami bahwa tafsir 'ilmi adalah penafsiran al-Quran dengan pendekatan ilmu pengetahuan. Dari definisi ini kita juga mengetahui bahwa ayat-ayat al-Quran yang dijadikan objek penafsiran bercorak 'ilmi ini adalah ayat-ayat yang mengandung nilai-nilai ilmiah dan kauniyah (kealamaan).

Tafsir 'ilmi dibangun berdasarkan asumsi bahwa alQur'an mengandung berbagai macam ilmu, baik yang sudah di temukan maupun yang belum di temukan. Tafsir corak ini berangkat dari paradigma bahwa al-Qur'an disamping tidak bertentangan dengan akal sehat dan ilmu pengetahuan, alQur'an tidak hanya memuat ilmu-ilmu agama atau segala yang terkait dengan ibadah ritual, tetapi juga memuat ilmuilmu duniawi, termasuk hal-hal mengenai teori-teori ilmu pengetahuan. ${ }^{6}$

4 Supiana dan M.Karman, Ulumul Qur'an dan Pengenalan Metodologi Tafsir. (Bandung: Pustaka Islamika, 2002), hlm. 314

5 Abdul Mustaqim, Dinamika Sejarah Tafsir Al-Qur'an, Studi Aliran-Aliran Tafsir dari Periode Klasik, Pertengahan, Hingga Modern-Kontemporer. (Yogyakarta: Adab Press, 2014), hlm. 136-137

${ }^{6}$ Ibid. hlm. 137 
Tafsir 'ilmi pada intinya adalah merupakan sebuah upaya untuk mengeksplorasi ayat-ayat yang terdapat dalam al-Qur'an khususnya ayat-ayat kauniyyah dengan berbagai cara dan metode sehingga dengan penafsiran ini akan dihasilkan teori-teori baru ilmu pengetahuan ataupun sesuatu yang berkesesuaian dengan ilmu pengetahuan modern yang ada pada saat ini. Sehingga penafsiran ini tidak dianggap sebagai sebuah "kelatahan" yang hanya berusaha men"justifikasi" setiap temuan-temuan sains saat ini sebagai sesuatu yang sudah terdapat di dalam al-Qur'an.

\section{Sejarah perkembangan tafsir 'ilmi}

Corak penafsiran ilmiah ini telah lama dikenal. Benihnya bermula pada Dinasti Abbasiyah, khususnya pada masa pemerintahan Khalifah Al-Ma'mun (w.853 M) , pada masa pemerintahan Al-Ma'mun ini muncul gerakan penerjemahan kitab-kitab ilmiah dan mulailah masa pembukuan ilmu-ilmu agama dan science serta klasifikasi, pembagian dan bab-bab dan sistematikanya.$^{7}$

Tafsir terpisah dari hadits, menjadi ilmu yang berdiri sendiri dan dilakukanlah penafsiran terhadap setiap ayat alQur'an dari awal sampai akhir. Al-Ma'mun sendiri merupakan putra khalifah Harun al-Rasyid yang dikenal sangat cinta dengan ilmu. Salah satu karya besarnya yang terpenting adalah pembangunan Bait al-Hikmah, pusat penerjemahan yang berfungsi sebagai perguruan tinggi dengan perpustakaan yang besar. Pada masa inilah, Islam mencapai peradaban dalam Kehidupan Masyarakat.(Bandung: PT Mizan Pustaka,1992), hlm. 154 
yang tinggi sebagai pusat kebudayaan dan ilmu pengetahuan dunia. ${ }^{8}$

Munculnya kecenderungan ini sebagai akibat pada penerjemahan kitab-kitab ilmiah yang pada mulanya dimaksudkan untuk mencoba mencari hubungan dan kecocokan antara pernyataan yang diungkapkan di dalam alQur'an dengan hasil penemuan ilmiah (sains). Gagasan ini selanjutnya ditekuni oleh imam al-Ghazali dan ulama-ulama lain yang sependapat dengan dia. Rekaman akan fenomena ini antara lain dituangkan oleh Fahru al-Razi dalam kitabnya Mafatih al-Ghaib. Bisa dikatakan, Fakhruddin ar-Razi (w. 606 H) patut untuk dikedepankan ketika kita membahas munculnya penafsiran secara ilmiah. Hal ini diakui oleh seluruh penulis Ahlussunnah dan riset lapangan juga membuktikan hal tersebut.

Sebelum Fakhruddin, al-Ghazali (505 H) dalam bukunya, Jawahir Al-Qur'an juga telah menyebutkan penafsiran beberapa ayat al-Qur'an yang dipahami dengan menggunakan beberapa disiplin ilmu, seperti: astronomi, perbintangan, kedokteran, dan lain sebagainya. Jika upaya alGhazali ini kita anggap sebagai langkah pertama bagi kemunculan penafsiran ilmiah, tidak diragukan lagi bahwa alGhazali sendiri belum berhasil merealisasikan metode tersebut, setelah satu abad berlalu, barulah Fakhrurrazi di dalam Mafatih al-Ghaib-nya berhasil merealisasikan metode penafsiran yang pernah menjadi percikan pemikiran alGhazali itu.

8 'Ali Hasan Al-'Aridl, Sejarah dan Metodologi Tafsir. (Jakarta: Rajawali Pers, 1992), hlm. 23 
Pasca masa Fakhrurrazi, tendensi penafsiran ilmiah (ini diteruskan dan menghasilkan buku-buku tafsir yang sedikit banyak terpengaruh oleh teori penafsiran Fakhrurrazi dalam ruang lingkup yang agak terbatas. Di antaranya adalah: Ghara'ib Al-Qur'an wa Ragha'ib al-Furqan, karya An-Nasyaburi (W. 728 H), Anwar at-Tanzil wa Asrar at-Ta'wil, karya AlBaidhawi (W. 791 H), dan Ruh al-Ma'ani fa Tafsir al-Qur'an alAdzim wa Sab'al-Matsani, karya Al-Alusi (W. 1217 H).

Melalui buku-buku tafsir itu, para pengarangnya telah melakukan penafsiran saintis atas ayat-ayat al-Qur'an. Selain mereka, terdapat beberapa mufassir lagi, seperti Ibn Abul Fadhl al-Marasi (W. 655 H), Badruddin az-Zarkasyi (W. 794 H), dan Jalaluddin as-Suyuthi (W. 911 H). Yang termasuk dalam golongan para mufassir yang memiliki tendensi penafsiran saintis. Meskipun demikian, sebenarnya para mufassir ini tidak dapat dimasukkan ke dalam kategori mufassirin yang memiliki aliran saintis dalam menafsirkan alQur'an, karena mereka hanya mengklaim bahwa al-Qur'an memuat semua jenis dan disiplin ilmu pengetahuan, dan hanya klaim ini tidak dapat dijadikan bukti bahwa mereka memiliki tendensi penafsiran saintis. Sebelum mereka pun, sebagian sahabat telah memiliki klaim yang serupa dan hingga kini tak seorang pun yang berani memasukkan para pengarang tersebut ke dalam kategori mufassirin yang memiliki tendensi penafsiran saintis.

Pasca periode tafsir Ruh al-Ma'ani, pada permualaan abad ke-4 Hijriyah, metode penafsiran saintis mengalami kemajuan yang pesat. Tercatat, para mufassir seperti: Muhammad bin Ahmad al-Iskandarani (W. 1306 H), dalam Kasyf al-Asrar an-Nuraniyah al-Qur'aniyah-nya, Al-Kawakibi 
(W. 1320 H), dalam Thaba'i al-Istibdad wa Mashari al-Isti'badnya, Muhammad Abduh (W.1325 H) dalam Tafsir Juz'Ammanya, dan Ath-Thanthawi (W.1358 H) dalam Jawahir al-Qur'annya, masing-masing menafsirkan ayat-ayat al-Qur'an secara saintis. Contoh penafsiran saintis al-Qur'an yang paling tampak jelas adalah buku tafsir al-Iskandarani dan athThanthawi di mana dengan sedikit perbedaan, mereka telah berusaha untuk memahami ayat-ayat al-Qur'an melalui ilmu pengetahuan empiris (tajribi) dan penemuan-penemuan manusia.

Pemikiran penafsiran secara ilmiah mengalami perkembangan yang lebih pesat sampai sekarang ini, sehingga memberi dorongan yang cukup besar bagi para ilmuan untuk menulis buku tafsir yang didasarkan atas pemikiran ilmiah secara tematik (al-maudhu'i). ${ }^{9}$

Menurut Dr.Abdul Mustaqim munculnya tafsir 'Ilmi ini karena dua faktor yaitu: Pertama, faktor internal yang terdapat dalam teks al-Qur'an, dimana sebagian ayat-ayatnya sangat menganjurkan manusia untuk selalu melakukan penelitian dan pengamatan terhadap ayat-ayat kauniah atau ayat-ayat kosmologi yang terdapat pada Q.S. al-Gasyiyah (88): 17-20), yang berbunyi :

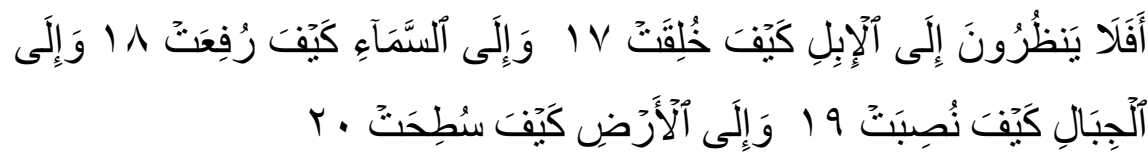

Artinya : Maka Apakah mereka tidak memperhatikan unta bagaimana Dia diciptakan, dan langit, bagaimana ia ditinggikan? dan gunung-gunung bagaimana ia ditegakkan? dan bumi bagaimana ia dihamparkan? ${ }^{10}$.

9 Hassan Ibrahim Hassan, Sejarah dan Kebudayaan Islam. (Yogyakarta: Kota Kembang, 1989), hlm. 136-140

10 Al-Qur'an dan Terjemahannya. (Jakarta: Media Insani, 2007). Hlm.592 
Ayat $17 \mathrm{~s} / \mathrm{d} 20$ perintah Allah ke pada manusia untuk bertafakur tentang alam semesta baik secara material maupun spiritual. Bukankah Allah swt menciptakan semua kejadian itu tidak sia-sia, melainkan ada rahasia yang ada di baliknya. Adalah sebagai bukti atas kekuasaan Allah yang maha kuasa atas segala sesuatu dan sebagai dalil rububiyah dan ilahiyah Allah azza wajalla. Rabbulalamin.

Tak dapat di sangkal lagi, bahwa kebangkitan kembali ilmu pengetahuan (scientific renaissance) yang timbul di dunia barat adalah berkat pengamatan yang cermat serta eksperimen terhadap gejala-gejala yang terdapat pada alam materi. Sekalipun kita tidak dapat mengakui orientasi mutlak dari hukum-hukum demikian itu, namun kita membenarkan bahwa hukum-hukum tersebut memberikan otentisitas dan ketetapan maksimum yang mungkin diperoleh. Hukumhukum ini secara berangsur-angsur bergerak menuju kesempurnaan sesuai dengan kemajuan ilmu pengetahuan. Dengan berlakunya masa dan meluasnya ilmu pengetahuan manusia, serta dengan semakin berkembangnya kecermatan di bidang pengamatan (observasi), maka para ilmuan dari waktu ke waktu memperkenalkan perubahan dan modifikasi dalam berbagai hokum ilmiah itu untuk lebih mendekatkannya kepada kenyataan, atau agar ia lebih memberikan hasil guna.

Ini berarti bahwa para ilmuan terus-menerus melakukan pekerjaan riset tentang alam semesta. Dalam upaya ini meraka menggunakan berbagai jenis materi untuk riset, terutama sekali adalah yang berkaitan dengan teori. Kemudian muncul setelah itu eksperimen di laboratorium, lapangan pertanian/peternakan atau dialam secara 
keseluruhan. Inilah yang di perintahkan oleh Al-Qur'an dalam hal memahami kenyataan-kenyataan, yang tertera di dalam ayat-ayat Al-Qur'an salah satunya pada surat Al-ghasyiyah ayat $17-20$.

Bahkan ada pula ayat-ayat al-Qur'an yang disinyalir memberikan isyarat untuk membangun teori-teori ilmiah dan sains modern, karena seperti dikatakan Muhammad Syahrur, wahyu al-Qur'an tidak mungkin bertentangan dengan akal dan realitas (revelation does not contradict with the reality).

Dengan asumsi tersebut, ayat-ayat al-Qur'an yang dapat dideduksi untuk menggali teori-teori ilmu pengetahuan, oleh sebagian ulama ditafsirkan dengan pendekatan sains modern, meskipun hal itu tidak pernah dilakukan oleh Nabi saw. dan para sahabat. Sebab para pendukung tafsir ilmi sependapat, bahwa penafsiran al-Qur'an sesungguhnya tidak mengenal titik henti, melainkan terus berkembang seiring dengan kemajuan sains dan ilmu pengetahuan. Sebagai contoh, ayat yang berbunyi khalaqa al-insana min 'alaq (Q.S. al-'Alaq (96): 2). Dulu, kata al-'alaq dalam ayat ini ditafsirkan oleh para mufasir klasik dengan pengertian segumpal darah yang membeku. Namun sekarang, dalam dunia kedokteran akan lebih tepat jika ditafsirkan dengan zigot, sesuatu yang hidup, yang sangat kecil menggantung pada dinding rahim perempuan.

Kedua, faktor eksternal, yakni adanya perkembangan dunia ilmu pengetahuan dan sains modern. Dengan ditemukannya teori-teori ilmu pengetahuan, para ilmuan muslim (para pendukung tafsir ilmi) berusaha untuk melakukan kompromi antara al-Qur'an dan sains dan mencari 'justifikasi teologis' terhadap sebuah teori ilmiah. Mereka juga 
ingin membuktikan kebenaran al-Qur'an (baca: i'jaz ilmi) secara ilmiah-empiris, tidak hanya secara teologis-normatif. ${ }^{11}$

\section{Tokoh - Tokoh Tafsir 'Ilmi dan Nama - Nama Kitabnya}

Telah di ungkapkan didalam sejarah munculnya tafsir 'ilmi bahwa tokoh yang paling gigih mendukung tafsir 'ilmi tersebut adalah Al-Ghazali (1059-1111 M) yang secara panjang lebar dalam kitabnya, Ihya' 'Ulum Al-Din dan Jawahir Al-Qur'an mengemukakan alasan-alasan untuk membuktikan pendapatnya itu. Al-Ghazali mengatakan bahwa "Segala macam ilmu pengetahuan, baik yang terdahulu (masih ada atau tidak ada), maupun yang kemudian baik yang telah diketahui maupun yang belum diketahui, semua bersumber dari Al-Qur'an Al-Karim". ${ }^{12}$

Tokoh-tokoh penggiat tafsir ilmi ini dari pengarang kitabkitab tafsir yang bercorak tafsir 'ilmi dintaranya :

1. Fakhrudin Al-Razi dengan karyanya Tafsir al-Kabir / Mafatih Al-Ghayib

2. Thanthawi Al-Jauhari dengan karyanya Al-Jawahir fi Tafsir al-Quran al-Karim

3. Hanafi Ahmad dengan karyanya Al-Tafsir al-'Tlmi li al-Ayat al-Kauniyah fi al-Qur'an

4. Abdullah Syahatah dengan karyanya Tafsir al-Ayat alKauniyah

5. Muhammad Syawqi dengan karyanya Al-Fajri Al-Isyarat Al'Tlmiyah fi al-Quran al-Karim

6. Ahmad Bayquni dengan karyanya Al-Qur'an Ilmu Pengetahuan dan Teknologi

${ }^{11}$ Abdul Mustaqim, "Kontroversi Tentang Tafsir Ilmi". Jurnal ilmu-ilmu al-Qur'an dan Tafsir, hlm. 5-6

12 M.Quraish Shihab. Membumikan Al-Qur'an, Fungsi dan Peran Wahyu dalam Kehidupan Masyarakat.(Bandung: PT Mizan Pustaka,1992), Hlm 154 
Dan tokoh-tokoh pengarang kitab-kitab tafsir yang berusaha menafsirkan ayat-ayat kauniyah dalam al-Qur'an misalnya:

1. Al-Allamah Wahid al-Din Khan dengan karya kitab tafsirnya al-Islam Yatahadda

2. Muhammad Ahmad Al-Ghamrawy dengan karya kitab tafsirnya Al-Islam fi 'Ashr al-'ilm

3. Jamal al-Din Al-Fandy_dengan karya kitab tafsirnya alGhida' wa al-Dawa'

4. Ustadz 'Abd al-Razzaq Nawfal dengan kitab tafsirnya AlQur'an wa al-'ilm Hadits ${ }^{13}$

Sedangkan menurut Abdul Majid Abdussalam alMuntasib, tokoh-tokoh penafsir ilmi kontemporer lainnya yaitu:

1. As-Syekh Muhammad Abduh.

2. Muhammad Jamaluddin al-Qasimi dalam Mahaasinu atTa'wil.

3. Mahmud Syukri al-Aluusi dalam buku Maa Dalli 'Alaihi alQur'anu Mimmaa ya'dhidu al-Hai'ata al-Jadiidata alQawiimatu al-Burhan (Dalil-dalil al-Qur'an yang meneguhkan ilmu astronomi modern, dengan argumentasi kuat).

4. Abdul Hamid bin Badis dalam Tafsiru Ibni Badis fii Majaalisi at-Tadzkiiri min Kalaami al-Hakimi al-Khabiir (Tafsir Ibnu Badis mengenai Firman Dzat Yang Maha Bijak dan Maha Tahu dalam forum-forum kajian).

13 Hassan Ibrahim Hassan. Sejarah dan Kebudayaan Islam. (Yogyakarta: Kota Kembang, 1989), hlm. 68 
5. Musthafa Shadiq ar-Rafi'i dalam bukunya I'jaazu al-Qur'ani wa Balaghtu an-Nabawiyah (Mukjizat al-Qur'an dan Balaghah Kenabian). ${ }^{14}$

\section{E. Metode Dalam Tafsir 'Ilmi}

Memanfaatkan ilmu pengetahuan manusia dengan tujuan untuk menguatkan kandungan ayat-ayat al-Qur'an adalah salah satu contoh dari usaha pengejawantahan metode tafsir ilmi atau tafsir saintis. Dalam metode penafsiran ini terdapat beberapa kaidah, diantaranya :

1. Kaidah Kebahasaan

Kaidah kebahasaan merupakan syarat mutlak bagi mereka yang ingin memahami Al-Qur'an. Baik dari segi bahasa Arabnya, dan ilmu yang terkait dengan bahasa seperti írab, nahwu, tashrif, dan berbagai ilmu pendukung lainnya yang harus diperhatikan oleh para mufassir. ${ }^{15}$

Kaidah kebahasaan menjadi penting karena ada sebagian orang yang berusaha memberikan legitimasi dari ayat-ayat Al-Qur'an terhadap penemuan ilmiah dengan mengabaikan kaidah kebahasaan ini. 16 Oleh karena itu, kaidah kebahasaan ini menjadi prioritas utama ketika seseorang hendak menafsirkan Al-Qur'an dengan pendekatan apapun yang digunakannya, terlebih dalam paradigma ilmiah.

2. Memperhatikan Korelasi Ayat

Seorang mufasir yang menonjolkan nuansa ilmiah disamping harus memperhatikan kaidah kebahasaan seperti yang telah disebutkan, ia juga dituntut untuk

${ }^{14}$ Ali Hasan Al-'Aridl. Sejarah dan Metodologi Tafsir, Terj. Ahmad Akram, cet. II (Jakarta : Raja Grafindo Persada, 1994), hlm. 62-63.

${ }_{15}$ M Nur Ichwan. Tafsir 'Ilmi Memahami Al Qur'an Melalui Pendekatan Sains Modern, (Yogyakarta: Menara Kudus, 2004), hlm. 161.

$16 \mathrm{Ibid}$. hlm. 162. 
memperhatikan korelasi ayat (munasabah al-ayat) baik sebelum maupun sesudahnya. Mufasir yang tidak mengindahkan aspek ini tidak menutup kemungkinan akan tersesat dalam memberikan pemaknaan terhadap AlQur'an. Sebab penyusunan ayat-ayat Al-Qur'an tidak didasarkan pada kronologi masa turunnya, melainkan didasarkan pada korelasi makna ayat-ayatnya, sehingga kandungan ayat-ayat terdahulu selalu berkaitan dengan kandungan ayat kemudian. $17 \quad$ Sehingga dengan mengabaikan korelasi ayat dapat menyesatkan pemahaman atas suatu teks.

3. Berdasarkan Fakta Ilmiah yang Telah Mapan

Sebagai kitab suci yang memiliki otoritas kebenaran mutlak, maka ia tidak dapat disejajarkan dengan teori-teori ilmu pengetahuan yang bersifat relatif. Oleh karena itu, seorang mufassir hendaknya tidak memberikan pemaknaan terhadap teks Al-Qur'an kecuali dengan hakikat-hakikat atau kenyataan-kenyataan ilmiah yang telah mapan dan sampai pada standar tidak ada penolakan atau perubahan pada pernyataan ilmiah tersebut, serta berusaha menjauhkan dan tidak memaksakan teori-teori ilmiah dalam menafsirkan Al-Qur'an. ${ }^{18}$ Fakta-fakta Al-Qur'an harus menjadi dasar dan landasan, bukan menjadi objek penelitian karena harus menjadi rujukan adalah faktafakta Al Qur'an, bukan ilmu yang bersifat eksperimental. ${ }^{19}$

17 Ibid. hlm. 163.

18 Ibid. hlm. 169.

19 Ahmad Fuad, Pasya. Dimensi Sains Al-Qur'an Menggali Ilmu Pengetahuan dari Al-Qur'an. (Solo : Tiga Serangkai. 2004). Hlm. 47. 


\section{Pendekatan Tematik}

Corak tafsir 'Ilmi pada awalnya adalah bagian dari metode tafsir tahlili (analitik). Sehingga kajian tafsir 'Ilmi pembahasannya lebih bersifat parsial dan tidak mampu memberikan pemahaman yang utuh tentang suatu tema tertentu. Akibatnya pemaknaan suatu teks yang semula diharapkan mampu memberikan pemahaman yang konseptual tentang suatu persoalan, tetapi justru sebaliknya, membingungkan bagi para pembacanya. 20

Ayat-ayat Al-Qur'an yang berbicara tentang konsep penciptaan manusia, yang dalam terminologi Al-Qur'an diilustrasikan sebagai suatu proses evolusi dengan menggunakan beberapa terminologi yang berbeda-beda. Satu sisi manusia diciptakan dari tanah, namun di sisi lain ia diciptakan dari air, atau air mani yang hina.

Jika ayat-ayat Al-Qur'an yang memiliki terminologi yang sama ini tetap dikaji secara parsial dan berdiri sendiri, tentu konsep yang dihasilkan pun juga bersifat parsial dan tidak utuh. Akibatnya, pemaknaan atas persoalan tersebut akan menjadi pertentangan dalam Al-Qur'an. ${ }^{21}$ Oleh karena itu pada perkembangannya, paradigma tafsir ilmiah menggunakan metode tafsir tematik yaitu penafsiran ayatayat dengan menentukan terlebih dahulu suatu topik, lalu ayat-ayat tersebut dihimpun dalam satu kesatuan yang kemudian melahirkan sebuah teori. ${ }^{22}$ Dengan demikian, bagi seorang mufassir 'Ilmi sebaiknya menghimpun seluruh ayat-

20 M. Nor. Ichwan, Tafsir Ilmy, Op. Cit., hlm. 171

21 Ibid., hlm. 171

22 Didin Saefuddin Buchori, Pedoman Memahami Al-Qur'an, (Bogor : Granada Sarana Pustaka, 2005). hlm. 216 
ayat Al-Qur'an yang mempunyai kesamaan tema pembahasan, sehingga dapat sampai kepada makna hakiki.

\section{F. Contoh - Contoh Ayat Tafsir 'Ilmi}

Contoh Q.S al-Baqarah (02): 61 yang bercerita tentang kaum Nabi Musa yang tidak puas dengan makan satu jenis makanan di pegunungan

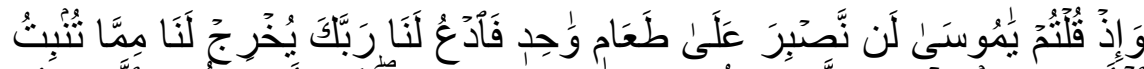

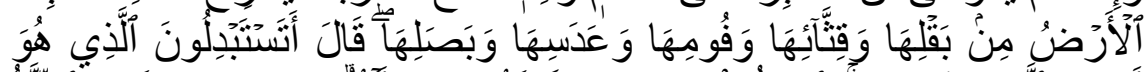

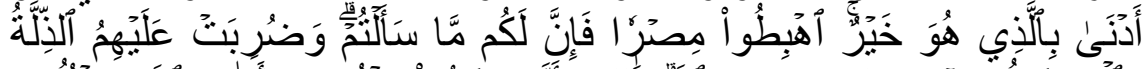

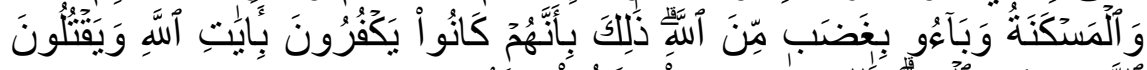

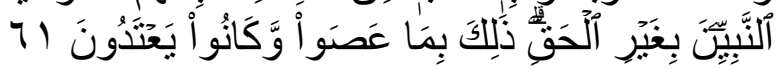

Artinya : Dan (ingatlah), ketika kamu berkata: "Hai Musa, kami tidak bisa sabar (tahan) dengan satu macam makanan saja. Sebab itu mohonkanlah untuk kami kepada Tuhanmu, agar Dia mengeluarkan bagi kami dari apa yang ditumbuhkan bumi, yaitu sayur-mayurnya, ketimunnya, bawang putihnya, kacang adasnya, dan bawang merahnya". Musa berkata: "Maukah kamu mengambil yang rendah sebagai pengganti yang lebih baik ?

Menurut Pendapat Thantowi Jauhari ayat ini dengan mengambil teori ilmiah Eropa, yakni bahwa model kehidupan Baduwi di pedesaan atau pegunungan, yang biasanya orang mengkonsumsi makanan manna wa salwa (jenis makanan yang tanpa efek samping) dengan kondisi udara yang bersih, jauh lebih baik daripada model kehidupan di perkotaan yang biasanya orang suka mengkonsumsi makanan siap saji, daging-daging, dan berbagai ragam makanan lainnya, ditambah lagi polusi udara yang sangat membahayakan kesehatan. 23

23 Tantawi Jauwhari, Al-Jawahir fi Tafsir al-Qur'an al-Karim al-Mushtamil 'ala 'Ajaib Badai' al-Mukawwanat wa Gharib al-Ayat al-Bahirat al-Musama 
Contoh lain dapat ditemukan dalam penafsiran $\mathrm{M}$. Abduh terhadap surat al-Fil (105): 3-4 yang menafsirkan kata thayran ababil (burung Ababil) dengan mikroba dan kata alhijarah (batu) dengan kuman penyakit. ${ }^{24}$ Atau, penafsiran Abdul al-Razq Nawfal pada Q.S. al-A'raf (07): 189

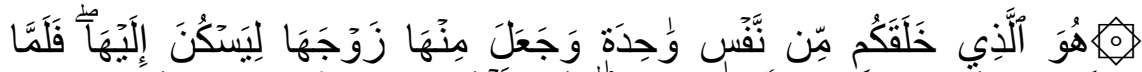

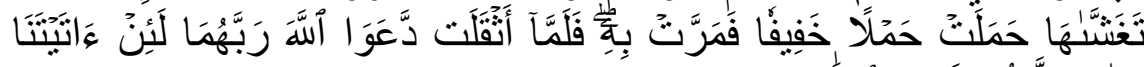

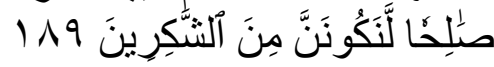

hua alldzi khalaqakum min al-nafsi al-wahidah waja'ala minha zawjaha, ia menafsirkan kata nafsu al-wahidah (diri yang satu) dengan proton dan zawjaha dengan pasangannya elektron, dan masing-masing keduanya membentuk unsur atom. ${ }^{25}$ Dapat dilihat juga dalam penafsiran ayat dalam surah Yasiin ayat 38:

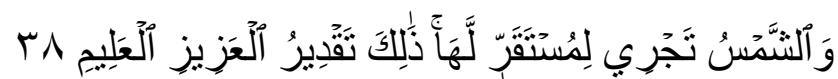
Artinya : Dan matahari berjalan ditempat peredarannya. Demikianlah ketetapan yang Maha Perkasa lagi Maha mengetahui. (QS. Yaasin: 38)

Pada masa-masa sebelumnya, para mufassir menafsirkan ayat ini dengan gerakan lahiriah matahari yang berjalan sehari-hari atau per musim. Akan tetapi, pada masa kini, berdasarkan penemuan-penemuan ilmiah dan sains baru, para ahli tafsir menafsirkan ayat tersebut dengan gerakan matahari menuju suatu titik tertentu yang di situ terdapat planet Vega. Semua penafsiran itu masih disertai dengan kehati-hatian dan bersifat moderatif. Akan tetapi, di

Tafsir Tantawi Jawhari, Juz 1 (Beirut: Dar al-Kutub al-'Ilmiyyah, 2004), hlm. 66-67

${ }^{24}$ M. Abduh, Tafsir Juz 'Amma (Mesir: Al-Jam'iyyah al-Khairiyyah, 1341 H), h. 5-6.

25 M. Rasyid Ridha, Tafsir al-Manar, (Mesir: Dar al-Manar, 1954), h. 208-212. 
beberapa kalangan mufassirin kita melihat keteledoran dan keberlebihan dalam menafsirkan ayat-ayat al-Qur'an dengan rangka mendukung metode penafsiran ilmiah. ${ }^{26}$ Urutan tahapan tersebut terwakili oleh dua ayat berikut:

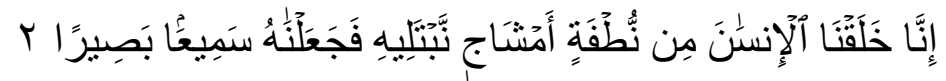

Artinya : "Sungguh, Kami telah menciptakan manusia dari setetes mani yang bercampur yang Kami hendak mengujinya (dengan perintah dan larangan), karena itu Kami jadikan dia mendengar dan melihat," (QS. al-Insan: 2).

Pada surah Al-Mu'minun: 13-14, dijelaskan, yang artinya :

"Kemudian Kami menjadikannya air mani (yang disimpan) dalam tempat yang kukuh (rahim). Kemudian, air mani itu Kami jadikan sesuatu yang melekat, lalu sesuatu yang melekat itu Kami jadikan segumpal daging, dan segumpal daging itu Kami jadikan tulang belulang, lalu tulang belulang itu Kami bungkus dengan daging. Kemudian, Kami menjadikannya makhluk yang (berbentuk) lain. Mahasuci Allah, Pencipta yang paling baik," (QS.).

Dr. Zaghlul an-Najjar mengatakan bahwa al-Qur'an membagi proses penciptaan manusia dalam tujuh tahapan yang teratur. Yaitu: 1. setetes mani (nuthfah); 2. Hasil dari peleburan ovum dan sperma (nuthfah amsaj); 3. Sesuatu yang melekat (alaqah); 4. Segumpal daging (mudhghah); 5. Pembentukan tulang (izham); 6. Pembungkusan tulangbelulang dengan daging; 7 . Pembentukan fetus yang sudah jelas.

26 Rohimin. Metodologi Ilmu Tafsir dan Aplikasi Model Penafsiran. (Yogyakarta: Pustaka Pelajar, 2007) hlm 97 
Maha suci Allah yang telah mempercayakan kesempurnaan fisik dan mental kepada kita setelah melewati proses penciptaan yang panjang dalam kehidupan ini. Tujuan Allah SWT memberikan kesempurnaan kepada kita adalah agar kita dapat melihat, mendengar, dan merasakan betapa besar dan luar biasa semua ciptaan-Nya. Maka dengan kesempurnaan yang didapat dari proses yang panjang itu, saudaraku, apa lagikah yang menyebabkan kita harus mengingkari kekuasaan-Nya sehingga kita tidak bersyukur atas apa-apa yang telah Dia berikan kepada kita?

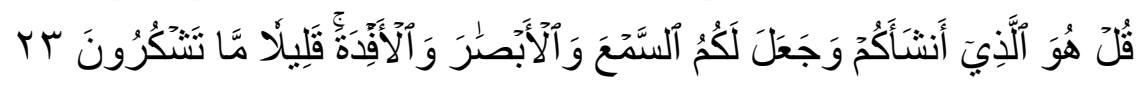

Artinya : "Katakanlah, 'Dialah yang menciptakan kalian dan menjadikan pendengaran, penglihatan dan hati nurani bagi kalian. (Tatapi) sedikit sekali kalian bersyukur','(QS. Al-Mulk: 23) 27.

Surah al-Mulk ayat 23 ini merupakan salah satu dari sekian banyak ayat yang berbicara tentang penciptaan manusia. Pada ayat ini, proses penciptaan manusia hanya disinggung sekilas lewat kata ansya 'akum. ${ }^{28}$

Perbincangan tentang seks senantiasa dikaitkan dengan persoalan aqidah, akhlak, menjauhi kemungkaran, dan tidak mendatangkan kemudahratan terhadap orang lain. Sebagai contoh, Qur'an telah menggambarkan institusi perkawinan sebagai sebuah institusi yang suci yang mampu memberikan ketenangan dan kasih sayang, hal ini sesuai dengan firman Allah SWT :

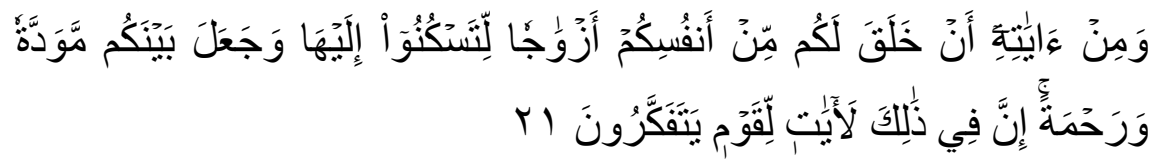

${ }^{27}$ Ibid

28 Ibid 
Artinya : Dan di antara tanda-tanda kekuasaan-Nya ialah Dia menciptakan untukmu isteri-isteri dari jenismu sendiri, supaya kamu cenderung dan merasa tenteram kepadanya, dan dijadikan-Nya diantaramu rasa kasih dan sayang. Sesungguhnya pada yang demikian itu benar-benar terdapat tanda-tanda bagi kaum yang berfikir. 29

Apabila membicarakan perkara yang berkaitan dengan penyelewengan seks seperti zina, Allah SWT menegaskan dalam A1-Qur'an :

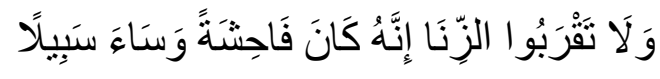

Artinya : Dan janganlah kamu mendekati zina; sesungguhnya zina itu adalah suatu perbuatan yang keji dan suatu jalan yang buruk. ${ }^{30}$

Apabila menyentuh persoalan hubungan homoseksual seperti yang di kisahkah melalui kaum Nabi Luth As, Allah SWT mengecam melalui dalil yang berbunyi :

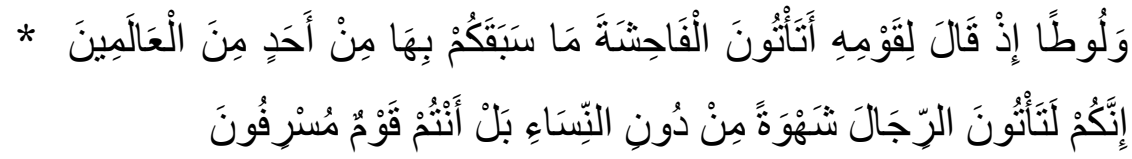

Artinya : Dan (Kami juga telah mengutus) Luth (kepada kaumnya). (Ingatlah) tatkala dia berkata kepada mereka: "Mengapa kamu mengerjakan perbuatan faahisyah (homoseksual) itu, yang belum pernah dikerjakan oleh seorangpun (di dunia ini) sebelummu?. Sesungguhnya kamu mendatangi lelaki untuk melepaskan nafsumu (kepada mereka), bukan kepada wanita, malah kamu ini adalah kaum yang melampaui batas. ${ }^{31}$

Islam sangat mementingkan umatnya menjalani kehidupan seksual yang sempurna dan baik selaras dengan tuntunan Allah SWT. Segala perintah dan peraturan agama 
berkaitan dengan seksual yang ditetapkan oleh Islam adalah kepada kesejahteraan hidup manusia.

\section{G. Pendapat Para Ulama Tentang Tafsir 'Ilmi}

Tafsir ilmi berusaha menafsirkan ayat Al-Qur'an berusaha mengukuhkan berbagai istilah ilmu pengetahuan dan berusaha melahirkan berbagai ilmu baru dalam AlQur'an. ${ }^{32}$ Dalam tafsir ini umumnya membahas tentang alam dan kejadian-kejadiannya (kauniyah) dan berusaha untuk membuktikan bahwa di dalam Al-Qur'an terdapat semua ilmu atau pengetahuan yang ada di dunia ini, baik yang telah lewat maupun yang akan datang. Bahkan menurut mereka (yang menggandrungi tafsir ilmi ini) masih banyak ilmu yang belum tergali dalam Al-Qur'an. Kelahiran corak penafsiran ini bersamaan dengan kemajuan pesat kebudayaan Islam. Tuntutuan perkembangan ilmu juga mendorong penafsiran secara ilmiah. ${ }^{33}$ Dari ulama klasik, yang mendukung penafsiran semacam ini di antaranya adalah :

1. Al-Ghazali, adalah orang yang paling banyak memasarkan tafsir ilmiah di tengah percaturan keilmuan Islam. Dalam kitabnya Ihya' 'ulumuddin pada pasal IV menyinggung mengenai pemahaman dan penafsiran al-Qur'an secara rasional tanpa menggunakan Naqal (Al-Qur'an dan Hadits). Beliau sepakat dengan pendapat beberapa ulama bahwa alQur'an mengungkapkan 77.200 macam/buah ilmu, karena setiap kata merupakan sebuah ilmu. Dengan mengutip hadist dari Ibn Mas'ud yang menyatakan bahwa Nabi pernah bersabda:

32 Muhammad Hussein Adz-Dzahabi, Al-Tafsir Wa Al-Mufassiruun, (Kairo: Maktabah Wahbah, 2003) vol. II hlm 349

33 Fahd ibn Abdurrahman Al-Rumi, buhuts fi ushul al-tafsir wa minhajuhu, (t.tp: Maktabah al-Taubah, t.th) hlm 97 
عن ابن مسعود رضي الله عنه انه قال: من اراد علم الآولين و لاخرين فليتدبر القران (رواه ابن مسعود)

Artinya: Barang siapa ingin memperoleh pengetahuan tentang beberapa permulaan dan beberapa kesudahan, maka kajilah al-Qur'an dengan seksama.

Beliau mengatakan bahwa segala sesuatu yang sulit dipahami dengan penginderaan dan penalaran sehingga menimbulkan berbagai teori yang berlawanan satu sama lain sebenarnya sudah dikemukakan dan dirumuskan dalam al-Qur'an dan semuanya dapat diketahui oleh para pemikir. ${ }^{34}$

2. Dalam ayat tersebut Allah SWT mendorong untuk melakukan perenungan dan pemikiran tentang bagaimana kejadian tersebut.

3. Dengan menggunakan pendekatan tafsir ilmi, penemuanpenemuan baru bisa digunakan sebagai penegasan terhadap kemukjizatan yang terdapat dalam Al-Qur'an.

4. Allah SWT akan mengisi jiwa seseorang dengan keimanan terhadap keagungan-Nya ketika ia menafsirkan Al-Qur'an dengan ayat-ayat tertentu dan makhluk-makhluk yang sangat renik dengan menggambarkannya melalui ilmu pengetahuan yang ada.

Sedangkan orang-orang yang menolak adanya penafsiran macam ini terhadap Al-Qur'an berargumen:

1. Kemukjizatan Al-Qur'an ialah sudah menjadi suatu yang pasti dan tidak butuh hal-hal lain untuk menjelaskannya seperti penafsiran macam ini terkadang bisa mengaburkan kemukjizatan Al-Qur'an.

${ }^{34}$ Al-Ghozali. Ihya' 'Ulumuddin Jilid I. (Kairo: Al-Tsaqofah al-Islamiyah, 1356 H) hlm. 301 
2. Dorongan Al-Qur'an untuk melakukan penalaran dan perenungan pada peristiwa dan ilmu-ilmu merupakan suatu ajakan yang menyeluruh dan bersifat pengambilan pelajaran (i'tibar), bukan untuk menjelaskannya secara mendalam dan menggali ilmu-ilmunya.

3. Penafsiran dengan corak ini memaksa penafsir untuk melakukan "lompatan yang jauh" dalam memaknai dan manafsirkan ayat Al-Qur'an dari makna luar (zhahir) ayat tersebut.

4. Tafsir ilmi menjerumuskan orang yang mendalaminya pada kesalahan dalam mengkompromikan dua istilah dari dua kutub yang berbeda (Al-Qur'an dan ilmu pengetahuan sains)

5. Ilmu-ilmu yang tergali dalam penafsiran ini hanya bersifat sementara dan akan berubah ketika ada penemuanpenemuan baru yang lebih besar. Hal ini membuat AlQur'an tidak bisa untuk menemukan pijakan sebagai sumber dari segala ilmu, karena terus berubah penafsirannya. ${ }^{35}$

Di antara yang menolak adanya penafsiran seperti ini adalah Abu Ishaq Al-Syatibi (w. 790 H) yang disampaikannya dalam kitab al-muwafaqat.

\section{H. Kesimpulan}

Dari pembahasan di atas, ada beberapa hal yang dapat penulis simpulkan, yaitu:

Tafsir 'ilmi adalah tafsir yang menggunakan istilahistilah ilmiah dalam mendiskripsikan al-Qur'an dan berusaha

35 Tim Forum Karya Ilmiah RADEN (refleksi anak muda pesantren), AlQur'an Kita Studi Ilmu, Sejarah Dan Tafsir Kalamullah, (Kediri: Lirboyo Press, 2011) hlm 248-249 
keras untuk mengeluarkan berbagai ilmu pengetahuan dan visi filsafat darinya.

Dalam menanggapi tafsir 'ilmi ini, para ulama ada dua kelompok yakni menolak dan mendukung. Bahkan banyak ulama-ulama kontemporer yang bersikap lebih moderat seperti al-Ghamrawi.

Kita tidak bisa mengklaim kebenaran bahwa teori-teori ilmiah ini adalah sebagai bentuk final dari penafsiran ayat, dalam artian al-Qur'an adalah bukan kitab ilmu pengetahuan melainkan kitab yang menjadi petunjuk dan rahmat bagi kehidupan manusia baik spiritual maupun material yang bisa dikembangkan melalui ilmu pengetahuan. 
Rubini : Tafsir 'Ilmi

\section{DAFTAR PUSTAKA}

Abdul Majid Abdussalam al-Muntasib. Visi dan Paradigma Tafsir Al-Qur'an Kontemporer, terj. Mohammad Maghfur Wachid. Judul asli Ittijaahat at-Tafsiir fi al-Ashri ar-Rahin. Bangil: AlIzzah, 1997

Abdul Mustaqim. Dinamika Sejarah Tafsir Al-Qur'an, Studi AliranAliran Tafsir dari Periode Klasik, Pertengahan, Hingga Modern-Kontemporer. Yogyakarta: Adab Press, 2014

Abdul Mustaqim, “Kontroversi Tentang Tafsir Ilmi”. Jurnal ilmuilmu al-Qur'an dan Tafsir,

Ahmad Fuad, Pasya. Dimensi Sains Al-Qur'an Menggali Ilmu Pengetahuan dari Al-Qur'an. Solo : Tiga Serangkai. 2004

Al-Ghozali. Ihya' 'Ulumuddin Jilid I. Kairo: Al-Tsaqofah alIslamiyah, $1356 \mathrm{H}$

Ali Hasan Al-'Aridl, Sejarah dan Metodologi Tafsir. Jakarta: Rajawali Pers, 1992

Al-Qur'an dan Terjemahannya. Jakarta: Media Insani, 2007

Didin Saefuddin Buchori, Pedoman Memahami Al-Qur'an, Bogor : Granada Sarana Pustaka, 2005

Fahd ibn Abdurrahman Al-Rumi, buhuts fi ushul al-tafsir wa minhajuhu, (t.tp: Maktabah al-Taubah, t.th

Hassan Ibrahim Hassan. Sejarah dan Kebudayaan Islam. Yogyakarta: Kota Kembang, 1989

M. Abduh, Tafsir Juz 'Amma. Mesir: Al-Jam'iyyah al-Khairiyyah, $1341 \mathrm{H}$

Muhammad Hussein Adz-Dzahabi, Al-Tafsir Wa Al-Mufassiruun, Kairo: Maktabah Wahbah, 2003

M Nur Ichwan. Tafsir 'Ilmi Memahami Al Qur'an Melalui Pendekatan Sains Modern, Yogyakarta: Menara Kudus, 2004 
Muhammad Nor Ichwan. Memasuki Dunia Al-Qur'an. Semarang: Lubuk Raya, 2001

M.Quraish Shihab, Membumikan Al-Qur'an, Fungsi dan Peran Wahyu dalam Kehidupan Masyarakat. Bandung: PT Mizan Pustaka, 1992

M.Quraish Shihab, Wawasan Al-Qur'an: Tafsir Maudhu'i Atas Pelbagai Persoalan Umat, Cet.VIII. Bandung: Mizan, 1998

Rohimin. Metodologi Ilmu Tafsir dan Aplikasi Model Penafsiran.Yogyakarta: Pustaka Pelajar, 2007

Supiana dan M.Karman, Ulumul Qur'an dan Pengenalan Metodologi Tafsir. Bandung: Pustaka Islamika, 2002

Tantawi Jauwhari, Al-Jawahir fi Tafsir al-Qur'an al-Karim alMushtamil 'ala 'Ajaib Badai' al-Mukawwanat wa Gharib alAyat al-Bahirat al-Musama Tafsir Tantawi Jawhari, Juz 1 . Beirut: Dar al-Kutub al-'Ilmiyyah, 2004

Tim Forum Karya Ilmiah RADEN. refleksi anak muda pesantren, Al-Qur'an Kita Studi Ilmu, Sejarah Dan Tafsir Kalamullah, Kediri: Lirboyo Press, 2011 